\title{
The Final Station (Umschlagplatz)
}

Author: Jarosław Marek Rymkiewicz

First Published: 1988

Translations: French (La dernière gare: Umschlagplatz, 1989); Dutch (Umschlagplatz, 1990); German (Umschlagplatz, 1993); English (The Final Station: Umschlagplatz, 1994).

About the Author: Born in 1935, Rymkiewicz is a poet, playwright, essayist, researcher of Polish literature (and former professor at the Institute of Literary Research in Warsaw) and translator of Anglo-American and Spanish poetry. Rymkiewicz's poetic work is inscribed in the twentieth-century revisions of Classicism, which plays with the poetry of culture, while his scientific interests focus on the Polish Baroque and Romanticism.

Further Important Publications: Eurydyka, czyli każdy umiera tak, jak mu wygodniej (Eurydice, or Everybody Dies the Way He Is Comfortable With, 1957; theatre play); Czym jest klasycyzm: manifesty poetyckie (1967, What Is Classicism: Poetic Manifests; essay); Król Mięsopust (1977, The Carnival King; play); Ulica Mandelsztama i inne wiersze $z$ lat 1979-1983 (1983, Mandelstam Street and Other Poems From 1979-1983; poetry); Rozmowy polskie latem 1983 (1984; Polish Talks in the Summer of 1983; novel); Kinderszenen (2008, Children's Scenes; historical sketches).

\section{Content and Interpretation}

The Final Station was first published abroad before being released in Poland (following the fall of communism in 1989) to immediate critical acclaim. On the one hand, the 1980s were a period when Polish literary production avidly took up Jewish themes, restoring their place in the national culture after a long period of omission a period of reflection on the meaning of the Holocaust. In spite of this, or because of it, it was a period when issues in Polish-Jewish relations were considered predominantly in the historical perspective, as a thing of the past. Through fictionalised testimony, Rymkiewicz's novel speaks to the collective consciousness of that era, dealing specifically with the Warsaw Umschlagplatz, a square where Jews were assembled for deportation to the Nazi death camps. Since the square itself has ceased to exist and is largely forgotten, the novel serves to reconstruct its topography and location in relation to other streets. Reading various historical documents, mainly memoirs and stories, the author tries to determine the exact location of the square in 1980s Warsaw, a particularly difficult task given that the whole "Jewish district” was demolished by the Germans during the war as punishment for the Warsaw Ghetto Uprising.

Ә Open Access. () 2021 Beata Przymuszata, published by De Gruyter. (c) BY-NC-ND This work is licensed under a Creative Commons Attribution-NonCommercial-NoDerivatives 4.0 License.

https://doi.org/10.1515/9783110671056-041 
More significantly, what is entailed in the search for the Umschlagplatz (literally "reloading point") is an attempt to understand how the city reacted to the deportation of its Jewish inhabitants. A declaration precedes this part of the book: "What is meant by Polish life, by Polish spirituality? What does it mean - what might it mean for our future - that we live around the place of their death?” (Rymkiewicz, 1992, p. 10). The novel evokes the prewar period by means of a fictional story set in the summer resort at Otwock (Paziński's $\rightarrow$ The Boarding House). Conversations at the summer resort are accompanied by the shadow of impending danger. The main character in these fragments, Icyk Mandelbaum, expresses views that resemble those of Rymkiewicz, so that he appears as a surrogate for the author (Marzec, 2005, p. 48; Krupa, 2013, p. 126). Yet various fictional elements point to something that lies beyond the author's biography, inviting the reader to engage with the text along lines of conjecture and imagination, rather than compelling them to "follow the map through Warsaw".

At the same time, these fictional elements do not suggest a less credible account, but rather expose the creative and ethical process that such an account must inevitably engage with. Just as the search for the Umschlagplatz traces the invisible course of the disappearance of a place, both physically and mentally, the process of reconstruction undertaken by the novel functions as the expression of a wish which, due to the shift in time, cannot be entirely authentic. Turning attention to this aspect of Rymkiewicz's writing, some researchers have pointed out the self-reflexive nature of the book. The quest to reconstruct a place, in this sense, is a reflection on the nature of creating the text, with implications for the ethical limitations of any narrative treatment of the Holocaust. (Marzec, 2005, p. 38; Krupa, 2013, pp. 132-138). The writer's transformation is further complicated by questions of identity, since his search for the Umschlagplatz runs through the reconstruction of his own family history. Yet even though his childhood was marked by war, he emphasises, it was not marked by the trauma experienced by Jewish children. As he writes in one passage comparing a wartime photograph of a young boy with a photograph taken by a German soldier of a Jewish child with his hands raised, "S. I regard it as something highly indecent that we Christian children were allowed to play, laugh and enjoy life" (Rymkiewicz, 1992, p. 23). The novel thus dwells on the important differences between the two experiences, an identity-exploring perspective on the Shoah that allows the writer to claim that his book is a lament for the dead and at the same time for himself: "A Pole who has been abandoned forever by his Polish Jews" (p. 100). Undoubtedly, the somewhat exalted tone of this statement may weaken the message of the work. At the same time, however, we should not forget that some of the topics the novel depicts - the problem of blackmail, for instance - were considered to be a brave gesture in the 1980s. Rymkiewicz's book ends with an indication of the geographic location of Umschlagplatz, but it turns out to be an "absent" space. Not only is there nothing left of it, but its surrounding have been incorporated into a block of flats. Jacek Kuroń, who accompanies the writer, is initially outraged by the absence of any memorial at the site, but Rymkiewicz's words change his mind. The absence of the original square of the Warsaw Um- 
schlagplatz, the author explains, is memorialised by the people now living next door they themselves are a kind of "monument". This only raises the question - a rhetorical one - whether oblivion can be explained in this way. In 1988, a monument was erected on the basis of a design by Hanna Szmalenberg and Władysław Klamarus.

\section{Main Topics and Problems}

In its early reception, The Final Station was contextualised in the debate on the inexpressibility of the Holocaust. Grzegorz Marzec drew attention to the sublime poetics and ironic detachment of Rymkiewicz's style, especially in those passages where numerous memories and versions of history coexist, and the multivalent nature of facts is revealed (Marzec, 2005, pp. 29-35). This emphasises the problem of memory both in individual and cultural terms. According to Aleida Assmann, Ubertowska suggested reading Rymkiewicz's text as a story oscillating between looking for a "place of memory" and approaching "traumatic places”. A writer who wants to find Umschlagplatz tries to find the right words, finding instead that words are always insufficient. Paradoxically, this incessant writing about writing - the obsessively self-reflexive quality of the narrative - does not undermine but rather "enhances the 'effect of reality"” (Ubertowska, 2007, p. 245). In the process of searching for the memory of the Umschlagplatz, Rymkiewicz builds a kind of "anti-monument to the Shoah", one that emerges only to fade away again (Ubertowska, 2007, p. 247).

Alongside the intricacies of memory and expressive limits of language, The Final Station speaks to the problematics of historiography. While the accounts on the Umschlagplatz that Rymkiewicz is able to gather from various texts are not always consistent, he does not consider them as mutually exclusive. Rewriting his version of history, he does not try to create the impression that he seeks the truth, but instead a cultural story that reaches for the conventions of the "history of the uncommon", and becomes "a historian of someone else's mentality” (Krupa, 2013, p. 141). Other scholarly perspectives focus on the image of the writer as a witness. According to Anna Mach, for example, such attempts to deal with one's own feelings and experience of the history of the Shoah inevitably lead to sentimentality and kitsch (Mach, 2016, p. 155). Moreover, by focusing on Poles and their reactions, the writer tends to exclude the neighbouring Jewish residents, a tendency best demonstrated by the passage "Someone who is a Jew and a Pole cannot be either a Jew or a Pole" (Rymkiewicz, 1992, p. 156). This explicitly formulated exclusion may indicate an unconscious rejection of the truth about the relationship between Poles and Jews, or a strategy for avoiding it, with the result that "the special fate of the Jews is erased in The Final Station - from the words of witnesses, from archival photographs, from memories" (Marzec, 2016, p. 182). While such criticisms represent an important perspective on the novel, one must also consider Rymkiewicz's book was one of the earliest to call attention to the issue of the "absence" of Jews in Polish literature of the 1980s. 


\section{Cited Works}

Krupa, B. (2013). Opowiedzieć Zagładę. Polska proza i historiografia wobec Holocaustu (1987-2003). Kraków: Universitas. Mach, A. (2016). Świadkowie świadectw. Postpamięć Zagłady w polskiej literaturze najnowszej. Toruń: Wydawnictwo Naukowe Uniwersytetu Mikołaja Kopernika. Marzec, G. (2005). Holocaust, wzniosłość, ironia: przedstawianie nieprzedstawialnego w „Umschlagplatzu“ Jarosława Marka Rymkiewicza. Pamiętnik Literacki, 96(1), pp. 31-52. Rymkiewicz (1992). Umschlagplatz. Gdańsk: Oficyna Wydawnicza Ubertowska, A. (2007). Świadectwo - trauma - głos. Literackie reprezentacje Holokaustu. Kraków: Universitas.

\section{Further References}

Adamczyk-Garbowska, M. (2013). Polish Literature on the Holocaust. In: A. Rosen, ed., Literature of the Holocaust. Cambridge: Cambridge University Press, pp. 150-163. Michlic, J. (1991). Umschlagplatz. Polin. A Journal of Polish-Jewish Studies, (6), pp. 333-338, Stimmel, J. K. (2005). Holocaust Memory between Cosmopolitanism and Nation-Specificity: Monika Maron's Pawels Briefe and Jaroslav's Rymkiewicz Umschlagplatz. The German Quarterly, 78(2), pp. 151-171. Zechenter, K. (2003). Marek Rymkiewicz. In: S. Lillian Kremer, ed., Holocaust Literature: An Encyclopedia of Writers and Their Work. London: Routledge, pp. 1063-1066.

BP 